is evidence of the advance of civilization in the area, there are also signs of disturbance, presumably tribal. In the largest pit of the Iron Age a small hoard of late Roman coins, dating from A.D. 370-380, had been buried. In the same pit was a Saxon burial of the sixth or seventh century. The skeleton was well preserved, and with it were a knife and "scramasax". Excavations will be resumed during the Easter term, when it is hoped to determine the date of the villa with greater precision, as well as its relation to the cemetery.

\section{University Functions and Responsibilities}

THReE addresses to Victorian political organizutions by Dr. R. E. Priestley, when he was vicechancellor of the University of Melbourne, have been published under the title "The University and the National Life". In the first of these addresses, dealing with the finance and objectives of the University of Melbourne, Dr. Priestley attempts to summarize the functions of a university in a democratic country. First, he considers a university should admit and, if necessary, finance by scholarships, grants and loans, the pick of every generation of the youth of the State, irrespective of the class of homes or society they came from. The university's first duty should be to provide inspiring teaching and the means of full development of body, character and mind for its undergraduate students. For this purpose, research and investigation are essential and the staff must be large enough to ensure adequate contact with students as well as leisure for investigation. The university should aim at sending out graduates whose natural and recognized place would be the front ranks of the occupations they follow and who would be the natural leaders of their generation.

Dr. Priestrey also urged that a university should admit interest in, and a certain responsibility for, its men and women throughout their lives, and he stressed the importance of the university extension department as a means of stimulating and satisfying the desire for knowledge which, if democracy is to survive, must become the outstanding characteristic of the average citizen of the democratic state. A university, too, should be a reservoir of liberal and progressive thought, the defender and upholder of all that is best in the thought, customs and traditions in the lives of the people and the State. In his second lecture, on the university and rural interests, Dr. Priestley outlined the ways in which a university agricultural department could assist the farmer. Besides the training of men in the sciences of special importance to agriculture and the carrying out of research on fundamental problems which assists the building up of the fundamental knowledge needed to indicate to the technical worker the most profitable line of attack on his problems, Dr. Priestley stressed the value of the agricultural department as a source of unbiased opinion on agricultural matters. In his third address, on "A Free University", he referred to the value and importance of an adequate scholar- ship system and to the danger in Australia that, efficient representation of sectional views may cause selfish and sectional interests to prevail over national interests. An even graver danger might be the failure to secure the best possible recruits for Australian public services, and only when university graduates are freely recruited for such services is the university making its best contribution to the community.

\section{Staff and Student Stipends in Soviet Universities}

According to the Soviet Union Year Book Press Service, on November 12 the Soviet Government published a decree changing the regulations governing the payment of the academic staff at the higher educational institutions (universities) of the U.S.S.R. and increasing the stipends granted to students at these institutions. Under the new regulations, the academic staff will be paid on a staff salary basis, instead of on the old system of payment according to the number of hours worked. They will be able to hold a staff position at one higher educational institution only, though at liberty to engage in work at other higher educational or research institutions if they so desire. The salary rates for the upper staff are : directors of chairs at universities, 1,100-1,500 roubles per month (about $£ 42-56$ ), in accordance with length of service; professors, 1,000-1,300 roubles per month; senior lecturers, 700-900 roubles per month. Apart from their salaries, the members of staffs have the advantages of many social services, such as free medical treatment and free school and university education for their children. The new rates of State stipends granted to students at the universities are as follows: students taking a fiveyear course receive 130 roubles per month for the first year, 150 roubles per month for the second year, 175 roubles per month for the third and fourth years, and 200 roubles per month for the fifth year. Students taking a four-year course receive the same amounts for the first, second and third years, and 200 roubles per month for the fourth year. Students at the teachers' training colleges receive 130 roubles per month for the first year and 150 roubles per month for the second year. Stipends for postgraduate research students will be increased to 400 roubles per month. The number of higher educational institutions in the U.S.S.R. in 1936 was 700 , and the number of students in them in the educational year 1936-37 was 542,000 .

\section{Mitogenetic Rays?}

AN article entitled "An Experimental Study of the Problem of Mitogenetic Radiation", which forms Bulletin No. 100 of the National Research Council, Washington, D.C., will be welcomed by many who have waited for an authoritative statement on the reality or otherwise of this type of radiation. The authors, Alexander Hollaender and Walter D. Claus, have spent two years in order to prove or to disprove the existence of the so-called mitogenetic rays. These rays have been defined as radiation comprised between the wave-lengths $1900 \mathrm{~A}$. and $2500 \mathrm{~A}$., having an intensity of $10-1000$ quanta $/ \mathrm{cm} .{ }^{2} / \mathrm{sec}$, the claim 